\title{
Difficulties Facing The Educational Supervision Processes In The Public Schools Of The Governorate Of Jarash Directorate Of Education
}

\author{
Ahmad Badah, Ph.D., Al Balq'a Applied University, Jordon \\ Amal AL-Awawdeh, Ph.D., Al Balq'a Applied University, Jordon \\ Lubna Akroush, Ph.D., Al Balq'a Applied University, Jordon \\ Nayfah Al Shobaki, Ph.D., Applied University, Princess Alia University, Jordon
}

\begin{abstract}
This study attempts to identify the difficulties facing the educational supervision processes in the public schools of the Directorate of Education at Jarash Governorate, Jordan, by surveying the principals of these schools. The sample size consisted of (143) male and female principals in the Governorate of Jarash Directorate of Education. In order to achieve the objectives of this study, a questionnaire was constructed to identify the difficulties facing the educational supervision processes and consisted of (41) items that were distributed over three difficulty domains: administrative, technical and financial. The validity and reliability of the questionnaire was verified. The results reveal a medium degree of difficulty facing the educational supervision processes. Financial difficulties domain ranked first with a high degree, technical difficulties came in second with a medium degree, and finally administrative difficulties domain came in last with a medium degree. The results indicated no statistically significant differences attributed to the gender variable on the instrument performance as a whole. There is a statistically significant differences attributed to the years of experience, in favor of the experienced principals (10 years more). In the light of these results, the researchers recommend (1) initiation of financial and occupational incentives for distinguished educational supervisors, (2) initiate courses and workshops on the contemporary supervision trends; and (3) vitalize electronic communication among the educational supervisors and male and female principals of the schools, through exchanging the experience and information as a feedback, in order to overcome the difficulties facing the educational supervision in the schools.
\end{abstract}

Keywords: Educational Supervision Processes; Public Schools; Jarash, Jordon

\section{INTRODUCTION}

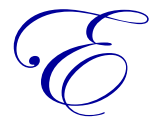

ducational supervision is one of the most important supports upon which the educational process is based. It is the main nursery of this process with all its aspects and components, such as the student, teacher, principal, and educational supervisor, as all these are complementary one to the other. One of the most of these is the educational supervisor, who is the sponsor of the process. He is the educational leader, who grasps the objectives sought to be realized, and works toward improving the learning-teaching process as well as developing it, to keep up with the accelerating information and communication technology in the digital age. The concept of the educational supervision developed and is no longer limited to "inspect" the teachers' performance or "evaluate" their works. Rather, it grew into a technical process aiming at preparing conditions for the continual teachers' development. It further aims at improving the learning-teaching process; and it requires cooperative efforts and group work, shared by all those concerned in the educational process interest. This process became more depending on planning, organizing and evaluating. 
The educational supervision is an integral part of the educational management, and is one of the important transactions in the educational system, especially in the learning and teaching processes. Even, it is deemed the cornerstone of developing the educational process of all its aspects, by assisting the teachers to improve their professional and personal growth through the use of various supervision methods. These methods include, for instance, classroom visits, educational workshops, study seminars, and training courses, in the light of the actual needs of the teachers. Educational management is in need for the educational supervision which serves as feedback to help in unveiling the errors, treating them, and developing the educational performance inside schools. Educational supervision is concerned in the student and the teacher equally, as well as in the method, in an ongoing interaction manner between the supervisor and the teacher, for the aim of improving the teaching and learning processes (Al-Saud, 2007).

The importance of the educational supervision stems of the concrete need for a permanent development system of education, and activating it in an educational field, as predetermined by the planned educational objectives. This will be only realized through a successful principal or supervisor, since supervision is the joining circle between all the educational inputs. Therefore, it is inevitably perceived that this system should be developed so as the education will achieve its optimal goal, that is building the human based on the important status of the supervision in the educational process (Al-Zayedi, 2002), (Al-Ghamidi, 2011).

Supervision importance further increases at this very time as a result of the accelerating changes the world experiencing in all life walks, as well as the information and technological developments in the education field. These developments were referred to by Sullivan \& Jeffery, (2002); Ting and Chang, (2006); and Safar, (2008), through the technological and technical development witnessed by the educational system. This mandates many of the stakeholders in the supervision domain call for developing it from the old styles into information technology based styles, through an interaction process between the supervisor and the teacher, on one hand, and the supervisors themselves on the other. The aim is improving their performance to reach the ultimate goal, i.e. improving the educational process in which the student is the pivotal concern. The increasing social demand on education, and the speed of the changes and renovations introduced into the managerial systems, supervision process grew more complicated. This is because the renovation practices, and leading today schools cannot be achieved through traditional methods which became contrary to the contemporary visions of the supervisors about the school role in a changing world. Thus, this managerial revolution, which is the offspring of the informational technology, created a state of administrative motion aiming at finding new alternatives to underline the difficulties that obstacle the supervision processes. It is inescapable to find new alternatives to deal with these difficulties and remove them, to ensure the school dynamicity in an age in which the constant variable is the change itself (Abdel Hakim \& Suleiman, 2006), (Atallah, 2011).

Educational supervision aims to develop the teaching-learning process of all the various educational environments, evaluate its outcomes to achieve the educational performance quality, through improving all influencing elements, and tackling the difficulties it faces, in the light of the dominant educational philosophy. This will lead to achieve the objectives indicated in the studies of Gordon, (2000), Narango, (1993), and Abdel-Hadi, (2002) as follows:

- $\quad$ Evaluation of the schools' performance; suggesting plans for modification, orientation and development in the light of the general goals of education in the community.

- $\quad$ Upgrading the professional, technical and administrative performance of the teachers.

- Improving the learning environment of teachers and helping them know the methods and values which could be achieved.

Based on the wish of the Ministry of Education in modernization and development, taking up with the world scientific, technological and educational developments, as well as the contemporary trends of the educational supervision in all its domains and areas, and making use of these domains as far as possible, in a manner that suits the scientific and technological international developments which decrease its effectiveness, and impedes its desired goals. Researchers find that its essential to reveal and examine these difficulties and their places, and deal with them in fruitful manner, in order to get the educational reform process become fruitful. Built on such feeling, this study came to handle the difficulties that the educational supervision processes face, and develop all its possible aspects. 
This could come true through assisting all the workers in education field, raising their productivity level in the educational field, within planned, organized and oriented toward the educational process inputs, to approach the desired educational goals.

\section{STUDY PROBLEM}

The problem of the study lies in answering the following questions:

- What are the difficulties experienced by the educational supervision processes in the public schools affiliated to the directorate of education in the Governorate of Jarash, as viewed by the principals of these schools?

- $\quad$ Are there statistically significant differences $(\alpha=0.05)$ in the differences faced by the supervision processes in the public schools affiliated to the directorate of education in the Governorate of Jarash, as viewed by the principals of these schools according to the (gender, years of experience) variables?

\section{STUDY OBJECTIVE}

This study aimed at revealing the difficulties that face the educational supervision processes in the public schools of Jarash Governorate in the practical field, in order to approach high level educational outputs .

The importance of this study is based on the critical importance of the educational supervision and its role in the learning-teaching process and takes up with the developments, as well overcoming the difficulties facing the supervision processes. In the light of the above, this study is important for the decision-makers in the Ministry of Education, and Jarash Governorate Directorate of Education, as this directorate is seeking to diagnose the most important difficulties facing the educational supervision processes to be taken into consideration when setting the future plans. Our aim of this study is to be made use of by the decision makers to provide facilities and necessary abilities to upgrade the supervision processes and overcome these difficulties.

\section{STUDY TERMS}

Educational Supervision: is an organized, planned process aiming at improving the teaching product through the introduction of suitable experiences to the teachers of the public schools in the Governorate of Jarash, Jordan, so as to release their energies and abilities, and avail the capabilities and condition that most fit good teaching, which in turn will lead to student's development, achievement, intellectually, practically and socially.

Difficulties: all the materialistic, administrative and technical hindrances that obstacle the educational supervisor's performance on his/her way to achieve the objectives of his/her supervisory programs, that are clear in improving and developing the teaching-learning process.

\section{STUDY LIMITS}

- Human Limits: Principals of the public schools in the Directorate of Education of Jarash Governorate, Jordan.

- $\quad$ Space Limits: The public schools in the Directorate of Education of Jarash Governorate, Jordan.

- $\quad$ Time Limits: This study had been applied during the first semester of the academic year 2012/2013.

- Thematic Limits: An instrument had been constructed to reveal the difficulties facing the educational supervision process, consisted of (41) items, distributed over three domains (Administrative, technical and materialistic).

\section{PREVIOUS STUDIES}

Researchers reviewed the following studies: 
Al-Harbi's (2006), which aimed at identifying the obstacles of the educational supervision, as seen by the supervisors, and the principals of the intermediate and secondary schools of Al-Rass Area, KSA. The study sample consisted of all the educational supervisors in the Directorate of Education and the supervisory centers of the Educational Department in Al-Rass area, Kingdom of Saudi Arabia (KSA). The results showed that the highest domains in terms of educational supervision obstacles were in the teacher's domain, as viewed by the supervisors and the secondary schools principals. It further found statistically significant differences attributed to the sex, years of experience and academic qualification degrees of both the supervisors and principals of these schools.

The study of Fitzgibbon (2004), aimed at identifying the challenges standing in the face of the developing the educational supervisors' professional efficiencies in a combined (mainstreamed) educational environment. The study sample of the study consisted of the educational supervisors in Glamourgon District. The study results indicated that one of the obstacles in the way of developing the supervisor' efficiencies was the lack for training programs that may cause them acquire efficiency in the use of technological aids. In the light of these results, the researcher suggested holding courses that may develop the supervisor's efficiencies in this area.

Idrees, (2002) conducted a study aimed at evaluating the directional practices in the Governorate of Irbid (Jordan), and identifying the difficulties facing the educational supervision process. The study sample comprised the supervisors of the education office, the teachers and principals of the core schools. To achieve the objectives of the study, the researcher constructed two questionnaires. First one consisted of (36) items directed to the teachers and principals about the supervisory practices carried out by the supervisors. The second consisted of (36) items directed to the supervisors and in-charge personnel of the supervision, to identify the technical and managerial difficulties that hinder the supervisory work. The study made several findings such as: there is a shortcoming of the supervisors in their field performance, and in ignoring many of their supervisory practices; many of them do not possess sufficient supervisory efficiencies; the field visits of the supervisors are scarce; and that there are no statistically significant differences attributed to the gender variable for the principals and teachers in evaluating the supervisory practices.

The study of Masa'adeh (2001) aimed at revealing the obstacles of educational supervision as viewed by the supervisors of the directorates of education in the northern governorate. It further aimed at identifying the effect of each of the gender, experience, academic degree and the interaction among them on the obstacles of educational supervision faced by the supervisors. The researcher employed the qualitative, analytic method, and the study sample consisted of (155) male and female supervisors. He employed a 63-item questionnaire distributed over the following domains: planning, method, education, professional growth, evaluation, educational management, classroom management, relationships with the colleagues and the local community. The results showed that the degree of educational supervision obstacles, as seen by the supervisors, was high; and that there were no statistically significant differences in the feeling degree of the supervisor of the obstacles that may be ascribed to the gender, academic degree, years of experience and the interaction among them.

Hazy, (1998) conducted a study aimed to identify the views of the supervisors at the level of Virginia State about the school reforms which took place in the State during (1982-1997). The study explored (47) supervisors through a questionnaire constructed to that purpose. In addition, the researcher interviewed (20) supervisors; and the result concluded that there is no surveillance on education; the supervisors indicated that the school reform is more than their capacities, because they feel themselves as monitoring tools, and curricula are the school reform tool.

\section{STUDY METHOD}

The study employed the survey qualitative method.

\section{Study Population and Sample}

Study population included all the male and female principals in the schools of the Directorate of Education of Jarash Governorate ( $\mathrm{n}=172$ ) (Ministry of Education, 2012). The reliance sample was excluded from the total population, as well as the data that did not fit the statistical analysis, so as to bring about the final number of the sample to (143) male and female supervisors of the Directorate of Education- Jarash Governorate. Table (1) illustrates the study sample distribution. 
Table (1) Distribution of the Study Sample

among the Male and Female School Principals of Directorate of Education- Jarash Governorate

\begin{tabular}{|l|c|c|c|}
\hline \multirow{3}{*}{ Variable } & Category & No. & Percentage \% \\
\hline \multirow{3}{*}{ Gender } & Male & 67 & $46 \%$ \\
\cline { 2 - 4 } & Female & 75 & $54 \%$ \\
\cline { 2 - 4 } & Total & 142 & $100 \%$ \\
\hline \multirow{3}{*}{ Years of Experience } & Less than 5 Years & 41 & $29 \%$ \\
& 5-10 Years & 59 & $41 \%$ \\
\cline { 2 - 4 } & 10 Years More & 42 & $30 \%$ \\
\cline { 2 - 4 } & Total & 142 & $100 \%$ \\
\hline
\end{tabular}

\section{Study Instrument}

To achieve the study objectives, the researchers developed a questionnaire by reference to the former studies, such as the studies of Atallah, (2011), Al-Harbi, (2006), and Al-Sarhan, (2001), and with reference to the theoretical framework of the difficulties facing the educational supervision in Jordan. The questionnaire in its initial form consisted of (47) items and included three areas of difficulties (administrative, technical and materialistic, that face the educational supervision. The five levels grading was employed to qualify the difficulty: very high degree $=$ 5 points, high degree $=4$ points, medium degree $=3$ points, low degree $=2$ points and very low degree $=1$ point.

\section{Instrument Validity}

To verify the instrument validity, the researchers employed the content validity, and the questionnaire was presented in its initial form to (12) arbitrators of the educational management and educational supervision in the Jordanian universities and the Ministry of Education. The researchers requested the arbitrators to assign their comments and views on the validity degree of the items and suitability to measure the difficulty degree facing the educational supervision in the Directorate of Education-Jarash Governorate, as viewed by the school principals; and to add any other item they deem fit. Then the arbitration questionnaire contents were taken, and the item with (10) arbitrators consensus was taken as a minimum (i.e. $83 \%$ more), taking into account the amendments, notes and additions. Items that were not approved by the arbitrators were excluded. Thus, the final version of the questionnaire contained 41 items including three domains: administrative, technical and materialistic.

\section{Instrument Reliability}

To ensure the reliability of the instrument, the researches made the test-retest to test a sample from outside the study sample ( $\mathrm{n}=18$, male and female principals). The instrument was distributed over them, and then redistributed two weeks later over the same sample, and then Pearson correlation coefficient was calculated. The reliability coefficients were between 0.87 and 0.91 for the domains. Furthermore, Chronbach Alfa reliability coefficients were calculated on the first test and were 0.85-0.92 for the domains. These coefficients are acceptable for the purposes of applying this study. Table (2) indicates the reliability coefficients of the study areas and the instrument as a whole.

Table (2) Test-Retest Reliability Coefficient and the Internal Consistency (Chronbach Alpha) for Each of the Study Instrument Areas

\begin{tabular}{|l|c|c|}
\hline \multicolumn{1}{|c|}{ Area } & Test-Retest Coefficient & Internal Consistency Coefficient \\
\hline Administrative Difficulties & 0.91 & 0.88 \\
\hline Technical Difficulties & 0.87 & 0.92 \\
\hline Materialistic difficulties & 0.89 & 0.85 \\
\hline The Instrument as a Whole & 0.90 & \\
\hline
\end{tabular}

\section{Statistical Processing}

The researchers analyzed the data and obtained the results using the Statistical Package of Social Sciences (SPSS) program, and the analyses were as follows: 
To answer question one, the M's and SD's were obtained, and for question two, the M's, SD's, t-test, ANOVA and Sheffe tests were employed to find out the statistically significant differences among the study variables groups. In order to judge the difficulty degree the supervisors face in the public schools in Jarash Governorate, as viewed by the school principals, the researchers followed the following order:

- $\quad$ Means less than 2.33 indicate little difficulty facing the educational supervision processes.

- $\quad$ Means 2.33-3.67 indicate medium difficulty facing the educational supervision processes.

- Means more than 3.67 indicate high difficulty facing the educational supervision processes.

\section{RESULTS AND DISCUSSION}

\section{First, Results And Discussion Of Question One}

What are the difficulties experienced by the educational supervision processes in the public schools affiliated to the directorate of education in the Governorate of Jarash, as viewed by the principals of these schools?

To answer this question, the means and SD's of the views of the school principals about the difficulties facing the educational supervision in the schools of Jarash Governorate Directorate of Education, were obtained according to the study domains. Table (3) illustrates this.

Table (3) Means and SD's of the Difficulty Degree Facing the Supervision Processes in the Schools of the Directorate of Education- Jarash Governorate, Arranged in a Descending Order by Mean (M)

\begin{tabular}{|c|c|c|c|c|c|}
\hline No. & Rank & Domain & Mean & SD & Difficulty Degree \\
\hline 3 & 1 & Materialistic difficulties & 4.08 & 0.78 & High \\
\hline 2 & 2 & Technical Difficulties & 3.26 & 0.75 & Medium \\
\hline 1 & 3 & Administrative Difficulties & 3.06 & 0.81 & Medium \\
\hline
\end{tabular}

Table (3) indicates the means which ranged between 3.06 and 4.08, where the materialistic difficulties were in the first rank with highest mean (4.08) and high degree as well; followed by the technical difficulties which ranked second with 3.26 mean and medium degree. Meanwhile the administrative difficulties ranked third with 3.06 mean and medium difficulty degree; and the mean of the instrument as a whole was 3.43 with a medium degree.

The means and SD's of the estimations of the study sample on the items of each area were calculated separately and were as follows:

\section{Administrative Difficulties}

Table (4) Means and SD's of the Administrative Domain Items on the Difficulties Facing Educational Supervision in the Public Schools of the Directorate of Education-Jarash Governorate, in a Descending Order by M's

\begin{tabular}{|c|c|l|c|c|c|}
\hline No. & Rank & \multicolumn{1}{|c|}{ Items } & M & SD & Difficulty Degree \\
\hline 4 & 1 & $\begin{array}{l}\text { Supervisor rarely visits the teachers because of large numbers } \\
\text { of teachers on his schedule. }\end{array}$ & 4.21 & 1.15 & High \\
\hline 3 & 2 & $\begin{array}{l}\text { Lots of administrative and participation duties burdening the } \\
\text { educational supervisor. }\end{array}$ & 3.91 & 1.12 & High \\
\hline 14 & 3 & $\begin{array}{l}\text { Some teachers are sometimes asked to teach subjects beyond } \\
\text { their specializations. }\end{array}$ & 3.85 & 0.94 & High \\
\hline 6 & 4 & $\begin{array}{l}\text { Weakness of the principals to practice supervision in schools } \\
\text { for all the subjects. }\end{array}$ & 3.74 & 0.95 & High \\
\hline 7 & 5 & $\begin{array}{l}\text { Absence of an accurate database about the teacher's training } \\
\text { needs. }\end{array}$ & 3.41 & 1.21 & Medium \\
\hline 11 & 6 & $\begin{array}{l}\text { Lack of a comprehensive supervision plan takes into account } \\
\text { the creativity of teachers. }\end{array}$ & 3.30 & 3.17 & Medium \\
\hline 13 & 7 & $\begin{array}{l}\text { Low application by the responsible people to the } \\
\text { recommendations of the supervisors for solving the problems } \\
\text { they face. }\end{array}$ & 3.25 & 0.85 & Medium \\
\hline
\end{tabular}




\begin{tabular}{|c|c|l|c|c|c|}
\hline 12 & 8 & $\begin{array}{l}\text { Supervision lacks for a decentralized leadership able to } \\
\text { contribute in its development. }\end{array}$ & 3.20 & 0.94 & Medium \\
\hline 9 & 9 & $\begin{array}{l}\text { Abrupt visits of the school, not considering the conditions of } \\
\text { its works. }\end{array}$ & 3.11 & 0.97 & Medium \\
\hline 2 & 10 & $\begin{array}{l}\text { Un-objective evaluation of the in-charge people to the } \\
\text { supervisors' works. }\end{array}$ & 3.50 & 1.19 & Medium \\
\hline 1 & 11 & $\begin{array}{l}\text { Ignorance of the educational supervisor's role in the teachers' } \\
\text { promotion system. }\end{array}$ & 3.01 & 3.18 & Ledium \\
\hline 15 & 12 & $\begin{array}{l}\text { Improper arrangements in preparing and implementing the } \\
\text { mutual visits among the teachers of various schools. }\end{array}$ & 2.11 & 1.05 & Little \\
\hline 8 & 13 & $\begin{array}{l}\text { Rarity of the visits of the supervisors outside the country to } \\
\text { attend educational and scientific conferences. }\end{array}$ & 2.07 & 1.06 & Little \\
\hline 10 & 14 & $\begin{array}{l}\text { Competition between the supervisor and the principal in } \\
\text { evaluating the teachers. }\end{array}$ & 1.95 & 0.87 & $\begin{array}{l}\text { Scarcity of accepting the supervisors' views when introducing } \\
\text { new educational programs. }\end{array}$ \\
\hline 5 & 15 & 1.74 & 1.84 & Little \\
\hline
\end{tabular}

Table (4) indicates that the M's ranged between 1.74 and 4.21, as item (4) providing "Supervisor rarely visits the teachers because of large numbers of teachers on his schedule', ranked first with (4.21) M and "high" estimation degree. This may be interpreted by that the educational administration, with its three levels: higher (Ministry of Education), medium (Directorate of Education), and executive (the School), poorly perceives the importance of the educational supervision processes in improving the educational process, in general; as well as increasing the students' achievement, in particular. This negatively reflects on the processes for planning, coordination, communication and monitoring the supervision processes. Moreover, such difficulties may also explained by that the supervisors do not possess skills of communication and continuation with the teachers, and skills for the modern evaluation basics to assess teachers; in addition to the insufficiency of the class visits (most often one visit a year) to evaluate the teacher. Also exists the poor coordination between the supervisor and the teacher, on one hand, and the supervisors and school management, on the other. This is attributed to the fact that the Ministry of Education (MOE) lacks clear educational plans, which cause to leave the effort of every supervisor far from the teamwork spirits. Meanwhile, item (5) providing: "Scarcity of accepting the supervisors' views when introducing new educational programs Scarcity of accepting the supervisors' views when introducing new educational programs" came last with 1.74 mean and little degree. Finally the mean of the domain, as a whole, was 3.06 and a medium estimation degree.

\section{Technical Difficulties}

Table (5) Means and SD's of the Technical Difficulties Domain Items Facing Educational Supervision in the Public Schools of the Directorate of Education-Jarash Governorate, in a Descending Order by M's

\begin{tabular}{|c|c|l|c|c|c|}
\hline No. & Rank & \multicolumn{1}{|c|}{ Items } & M & SD & $\begin{array}{c}\text { Difficulty } \\
\text { Degree }\end{array}$ \\
\hline 31 & 1 & $\begin{array}{l}\text { Low experience level of the supervisor in using the modern electronic } \\
\text { technologies. }\end{array}$ & 4.35 & 0.94 & High \\
\hline 28 & 2 & $\begin{array}{l}\text { Teacher's limited follow-up of the educational websites on the } \\
\text { educational supervision. }\end{array}$ & 4.21 & 0.85 & High \\
\hline 29 & 3 & $\begin{array}{l}\text { Limited follow-up of the teacher to the new developments in the } \\
\text { educational field through the various Medias. }\end{array}$ & 4.17 & 1.11 & High \\
\hline 34 & 4 & Poor loyalty of the teacher to the profession. & 3.92 & 0.92 & High \\
\hline 39 & 5 & $\begin{array}{l}\text { Low level of supervisors' revision to the recent research works and } \\
\text { studies in their field. }\end{array}$ & 3.92 & 0.92 & High \\
\hline 30 & 6 & $\begin{array}{l}\text { Confinement of the supervisors' role to the class visit without other } \\
\text { supervisory methods. }\end{array}$ & 3.80 & 0.87 & High \\
\hline 35 & 7 & Poor professional efficiency of some teachers. & 3.72 & 0.95 & High \\
\hline 32 & 8 & $\begin{array}{l}\text { Inaccuracy of the evaluation methods practiced by the educational } \\
\text { supervisors. }\end{array}$ & 3.61 & 1.17 & Medium \\
\hline 37 & 9 & Some teachers do not implement the directions of the supervisor. & 3.50 & 1.08 & Medium \\
\hline 36 & 10 & Evaluation works take place in the absence of the teacher. & 3.42 & 1.05 & Medium \\
\hline
\end{tabular}




\begin{tabular}{|c|c|l|c|c|c|}
\hline 40 & 11 & $\begin{array}{l}\text { Difficulties in accurately defining the required training skills for the } \\
\text { teacher. }\end{array}$ & 3.11 & 1.05 & Medium \\
\hline 33 & 12 & Curricula difficulties that lessen the role of the supervisor. & 3.05 & 0.95 & Medium \\
\hline 41 & 13 & $\begin{array}{l}\text { Principal's poor follow-up of the supervisor's recommendations to the } \\
\text { teacher. }\end{array}$ & 2.27 & 0.94 & Little \\
\hline 38 & 14 & Poor teacher's professional development programs. & 2.13 & 0.87 & Little \\
\hline \multicolumn{2}{|l|}{ The Instrument as a Whole } & 3.66 & 0.75 & Medium \\
\hline
\end{tabular}

Table (5) indicates that means ranged between 2.13 and 4.35, and item (31) providing "Low experience level of the supervisor in using the modern electronic technologies', ranked first with 4.35 mean and high degree. This may be attributed to the low technological efficiencies of many of the educational supervisors, so they will not be able to provide them to the teachers. Furthermore, many supervisors focus only on the class visit and far avoid modern supervisory practices, which are originally based on the necessity to keep up with the latest developments in our contemporary age in modern specialized technologies about the curricula. In addition, some supervisors concentrate on the theoretical aspect based on their own cognitive concepts of technology, far away of the applied practical side, which depends on providing technological abilities, such as interaction e-board inside the classrooms, which our public schools lack. This poses a difficulty to the supervisor to provide the teacher a variety of the modern technological education strategies, which need specialized experts in this field. Item (38) came last which provides "Poor teacher's professional development programs", with 2.13 mean and "little" degree. The mean of the domain, as a whole, was 3.26 with a medium degree.

Table (6) Means and SD's of the Materialistic Difficulties Domain Items Facing Educational Supervision in the Public Schools of the Directorate of Education-Jarash Governorate, in a Descending Order by M's

\begin{tabular}{|c|c|c|c|c|c|}
\hline No. & Rank & Items & M & SD & $\begin{array}{l}\text { Difficulty } \\
\text { Degree }\end{array}$ \\
\hline 20 & 1 & Material incentives to the teachers do not exist. & 4.58 & 0.98 & High \\
\hline 21 & 2 & Little financial incentives for the supervisor. & 4.47 & 0.93 & High \\
\hline 27 & 3 & $\begin{array}{l}\text { Absence of the materialistic reinforcement for research works on } \\
\text { educational supervision. }\end{array}$ & 4.41 & 0.82 & High \\
\hline 25 & 4 & $\begin{array}{l}\text { Rarity of external support for qualifying the educational } \\
\text { supervisors. }\end{array}$ & 4.40 & 1.13 & High \\
\hline 26 & 5 & $\begin{array}{l}\text { Poor supervision budget as compared to the factual educational } \\
\text { situation. }\end{array}$ & 4.35 & 1.15 & High \\
\hline 19 & 6 & $\begin{array}{l}\text { Low financial amount allocated to implement certain } \\
\text { supervisory methods. }\end{array}$ & 4.11 & 0.91 & High \\
\hline 16 & 7 & Limited modern supplies and equipments inside the classrooms. & 4.02 & 0.95 & High \\
\hline 23 & 8 & Rare ways required to monitor the class visits activities. & 3.91 & 0.97 & High \\
\hline 18 & 9 & Rarity of references and resources in the school libraries. & 3.85 & 1.11 & High \\
\hline 22 & 10 & $\begin{array}{l}\text { Lack of a central electronic library for the educational } \\
\text { supervision. }\end{array}$ & 3.61 & 1.21 & Medium \\
\hline 17 & 11 & $\begin{array}{l}\text { Difficulty in providing the transport means to the supervisor to } \\
\text { move among the schools. }\end{array}$ & 3.60 & 1.05 & Medium \\
\hline 24 & 12 & $\begin{array}{l}\text { Rarity of required abilities at schools to hold meetings, } \\
\text { educational and training workshops. }\end{array}$ & 3.54 & 1.17 & Medium \\
\hline \multicolumn{3}{|c|}{ The Instrument as a Whole } & 4.08 & 0.78 & High \\
\hline
\end{tabular}

\section{Materialistic Difficulties}

Table (6) illustrates that the means ranged between 3.54 and 4.58, with item (20) providing "' ranking first with 4.58 mean and "high" degree. This may be attributed to the rarity of financial allocations in the budget to accomplish supervision processes. There are no financial incentives for the distinguished teachers and supervisors; the materialistic reinforcement for their scientific research work is absent. Moreover, there are no funds allocated to qualify the supervisors to take up with the modern and contemporary developments in the field. The administration is well confined to the academic degree and practical experience of the supervisor, who focuses only on the theoretical aspect rather than the applied side in the supervision process. Therefore, the sufficient financial support is important to overcome many of the difficulties facing the supervisory process, which will positively affect raising 
the supervisory services provided by the teacher and school, and for his outstanding performance. Item (24) providing "Rarity of required abilities at schools to hold meetings, educational and training workshops." ranked last with 3.54 mean and $0.78 \mathrm{SD}$, and "medium" degree. The mean of the domain as a whole was (4.08) with a "high" degree.

\section{Second: Results and Discussion of Question Two}

Are there statistically significant differences $(\alpha=0.05)$ in the differences faced by the supervision processes in the public schools affiliated to the directorate of education in the Governorate of Jarash, as viewed by the principals of these schools according to the (gender, years of experience) variables?

For the answer of this question, the researchers obtained the M's and MD's of the difficulties degrees faced by the supervision processes as viewed by the school principals. To illustrate the differences, t-test was used as shown in Table (7).

Table (7) Means, SD's and T-tests of the Effect of Gender

on Estimating the Difficulty Degree Faced by the Educational Supervision, as Viewed by the Public Schools Principals

\begin{tabular}{|c|c|c|c|c|c|c|}
\hline Domain & Gender & No. & $\mathbf{M}$ & SD & Freedom Degrees & Significance \\
\hline \multirow[t]{2}{*}{ Administrative Difficulties } & Male & 65 & 1.11 & 0.74 & \multirow[t]{2}{*}{1.40} & \multirow[t]{2}{*}{0.24} \\
\hline & Female & 77 & 3.02 & 0.86 & & \\
\hline \multirow[t]{2}{*}{ Technical Difficulties } & Male & 65 & 3.21 & 0.71 & \multirow[t]{2}{*}{1.40} & \multirow[t]{2}{*}{0.18} \\
\hline & Female & 77 & 3.80 & 0.78 & & \\
\hline \multirow[t]{2}{*}{ Materialistic Difficulties } & Male & 65 & 4.13 & 0.93 & \multirow[t]{2}{*}{1.40} & \multirow[t]{2}{*}{0.14} \\
\hline & Female & 77 & 4.04 & 0.76 & & \\
\hline \multirow[t]{2}{*}{ Instrument as a Whole } & Male & 65 & 3.38 & 0.81 & \multirow[t]{2}{*}{1.40} & \multirow[t]{2}{*}{0.21} \\
\hline & Female & 77 & 3.47 & 0.82 & & \\
\hline
\end{tabular}

Table (7) shows no statistically significant differences $(\alpha=.05)$ attributed to the gender variable in all the domains and the instrument as a whole. This may be interpreted by the fact that the administrative and educational conditions are alike for both male and female schools; all of them live the same conditions within the same environment and one organizational culture, which is Jarash Directorate of Education. Further more, the same one supervisory authority is responsible for these schools, practicing centralized management style in decision taking concerning the supervision processes. This, in turn, contributes in the uniformity of the principals' views of these schools on the difficulty degree facing the supervision process. The results of the current study are in line with that of Masa'adeh (2001), Idrees (2002), but not in line with Al-Harbi's (2006).

The researchers further obtained the M's and SD's of the public schools principals' estimations of the difficulties facing the supervision processes according to the years of experience variable, as shown in Table (8).

Table (8) Means and SD's of the Public Schools Principals' Estimation of the Difficulty Faced by Supervision Processes According to the Years of Experience Variable

\begin{tabular}{|l|c|c|c|c|}
\hline \multicolumn{1}{|c|}{ Domain } & Category & No. & M & SD \\
\hline Administrative Difficulties & Less than 4 Years & 41 & 3.34 & 0.75 \\
\cline { 2 - 5 } & 5-10 Years & 59 & 3.01 & 0.79 \\
\cline { 2 - 5 } & 10 Years and More & 42 & 2.86 & 0.83 \\
\hline \multirow{3}{*}{ Technical Difficulties } & Less than 4 Years & 41 & 3.49 & 0.81 \\
\cline { 2 - 5 } & 5-10 Years & 59 & 3.24 & 0.77 \\
\cline { 2 - 5 } & 10 Years and More & 42 & 3.06 & 0.69 \\
\hline Materialistic Difficulties & Less than 4 Years & 51 & 4.32 & 0.67 \\
\cline { 2 - 5 } & 5-10 Years & 42 & 3.89 & 0.83 \\
\cline { 2 - 5 } & 10 Years and More & 41 & 3.63 & 0.74 \\
\cline { 2 - 5 } & Less than 4 Years & 59 & 3.42 & 0.89 \\
\cline { 2 - 5 } & 5-10 Years & 42 & 3.24 & 0.73 \\
\cline { 2 - 5 } & 10 Years and More & & \\
\hline
\end{tabular}


Table (8) indicates an apparent variance in the means and SD's of the school principals' estimations of the difficulties facing the supervision processes due to the difference in the years of experience variable. In order to illustrate the statistically significant differences among the means, ANOVA analysis was employed, as shown in Table (9).

Table (9) ANOVA Analysis of the Effect of Years of Experience on the Estimations of the Public Schools' Principals of the Difficulty Degree Facing the Educational Supervision Processes

\begin{tabular}{|c|c|c|c|c|c|c|}
\hline Domain & Categories & $\begin{array}{c}\text { Total } \\
\text { Squares }\end{array}$ & $\begin{array}{c}\text { Freedom } \\
\text { Degrees }\end{array}$ & F Value & Square Mean & Significance \\
\hline \multirow{3}{*}{$\begin{array}{l}\text { Administrative } \\
\text { Difficulties }\end{array}$} & Inter Groups & 3.40 & 2 & 1.698 & \multirow{3}{*}{7.461} & \multirow{3}{*}{0.01} \\
\hline & Intra Groups & 28.93 & 13 & 0.221 & & \\
\hline & Total & 32.23 & 141 & & & \\
\hline \multirow{3}{*}{$\begin{array}{l}\text { Technical } \\
\text { Difficulties }\end{array}$} & Inter Groups & 1.71 & 2 & 0.884 & \multirow{3}{*}{3.561} & \multirow{3}{*}{0.03} \\
\hline & Intra Groups & 31.05 & 139 & 0.239 & & \\
\hline & Total & 32.76 & 141 & & & \\
\hline \multirow{3}{*}{$\begin{array}{l}\text { Materialistic } \\
\text { Difficulties }\end{array}$} & Inter Groups & 1.62 & 2 & 0.741 & \multirow{3}{*}{3.773} & \multirow{3}{*}{0.02} \\
\hline & Intra Groups & 28.03 & 139 & 0.202 & & \\
\hline & Total & 29.65 & 141 & & & \\
\hline \multirow{3}{*}{$\begin{array}{l}\text { Instrument as a } \\
\text { Whole }\end{array}$} & Inter Groups & 2.08 & 2 & 1.073 & \multirow{3}{*}{5.908} & \multirow{3}{*}{0.000} \\
\hline & Intra Groups & 20.13 & 139 & 0.164 & & \\
\hline & Total & 22.21 & 141 & & & \\
\hline
\end{tabular}

Table (9) shows statistically significant differences at $(\alpha=0.05)$ among the means of the estimations of the study sample members on all the administration domains, that are attributed to the years of experience variable. In order to identify in whose favor the difference is, Scheffe test was carried out as illustrated in table (10).

Table (10) Scheffe Test Results of the Post Comparisons of the Study Sample Members' Means on all the Study Domains and the Instrument as a Whole, According to the Experience Variable

\begin{tabular}{|c|c|c|c|c|}
\hline Domain & Years of Experience & $\mathbf{M}$ & 5- Less than 10 Years & 10 Years and More \\
\hline \multirow{3}{*}{$\begin{array}{l}\text { Administrative } \\
\text { Difficulties }\end{array}$} & Less than 5 Years & 3.34 & \multirow{3}{*}{0.12} & \multirow{3}{*}{$\begin{array}{l}* 0.37 \\
* 0.27\end{array}$} \\
\hline & 5-10 Years & 3.01 & & \\
\hline & 10 Years and More & 2.86 & & \\
\hline \multirow{3}{*}{$\begin{array}{l}\text { Technical } \\
\text { Difficulties }\end{array}$} & Less than 5 Years & 3.49 & \multirow{3}{*}{0.15} & \multirow{3}{*}{$\begin{array}{l}* 0.31 \\
* 0.17\end{array}$} \\
\hline & 5-10 Years & 3.24 & & \\
\hline & 10 Years and More & 3.06 & & \\
\hline \multirow{3}{*}{$\begin{array}{l}\text { Materialistic } \\
\text { Difficulties }\end{array}$} & Less than 5 Years & 4.32 & \multirow{3}{*}{0.09} & \multirow{3}{*}{$\begin{array}{l}* 0.36 \\
* 0.27\end{array}$} \\
\hline & 5-10 Years & 4.05 & & \\
\hline & 10 Years and More & 3.89 & & \\
\hline \multirow{3}{*}{$\begin{array}{l}\text { Instrument as a } \\
\text { Whole }\end{array}$} & Less than 5 Years & 3.63 & \multirow{3}{*}{0.10} & \multirow{3}{*}{$\begin{array}{l}* 0.38 \\
* 0.28\end{array}$} \\
\hline & 5-10 Years & 3.42 & & \\
\hline & 10 Years and More & 3.24 & & \\
\hline
\end{tabular}

* Statistically significant at $(\alpha=0.05)$ significance level.

Table (10) indicates the existence of statistically significant differences at $(\alpha=0.05)$ significance level among the means of the estimations of the study sample members on all the instrument domains, and on the instrument as a whole, between the experienced members (less than 5 years and from 5 to 10 years), on one hand, and from 10 and more years, on the other, in favor of the latter group (10 years more). This may be attributed to the long experience they gained during their work and during many training courses and workshops, which increased their efficiency and perception of the difficulties facing the educational supervision in the field, as a result of their long experience, and its importance for them. This result is not in line with the study of Masaadeh, (2001) and study of Idrees, (2002). 


\section{RECOMMENDATIONS}

In the light of the results of this study, the researchers suggest:

- Finding a materialistic and occupational incentive system to award the outstanding people of the supervision processes.

- Work toward activation of courses and workshops for supervision processes.

- Increasing the number of the supervisors so as to reduce the number of teachers affiliated to the same one supervisor.

- Setting training programs for the educational supervisors in the field of effective and modern communication skills.

- Increasing the supplies and equipments levels in the public schools of the Ministry of Education for the Information Technology field, in order to support the applied aspects of the supervision processes.

\section{AUTHOR INFORMATION}

Ahmad Badah, Ph.D., Al Balq'a Applied University, Jordon

Amal AL-Awawdeh, Ph.D., Al Balq'a Applied University, Jordon

Lubna Akroush, Ph.D., Al Balq'a Applied University, Jordon

Nayfah Al Shobaki, Ph.D., Applied University, Princess Alia University, Jordon

\section{REFERENCES}

1. Abdel-Hadi, Jawdat. (2002), "Educational Supervision, Concepts and Methods, Guide to Improve Teaching", University of Jordan, Amman.

2. Abdel-Hakim Salameh \& Suleiman, Awadallah, (2006), "Modern Trends in Educational Supervision", Alexandria, Dar Al-Wafa Printing and Publication.

3. Al-Ghamidi, Turki Saleh Abdel-Karim (2011), "Use Effectiveness of the Electronic Applications in the Educational Supervision in Public Administration of Education, Mecca Mukarramah", Unpublished MA Thesis, Faculty of Education, Umm Durman University, Sudan.

4. Al-Harbi, Fahed Bin Jahaz Zaben, (2006), "Impediments of the Educational Supervision, as Seen by the Supervisors and the Intermediate and Secondary Schools' Principals in Al-Rass Educational Area, KSA"; Unpublished MA Thesis, Faculty of Education, University of Jordan, Amman.

5. Al-Saud, Rateb, (2007), "Educational Supervision, Modern Trends", $2^{\text {nd }}$ Ed, Dar Wa'el.

6. Al-Zayedi, Maha Mohammad Khalaf, (2003), "Evaluation of the Functional Performance of the Female Supervisor: An Applied Study", Dar Al-Fikr Al-Arabi, Cairo.

7. Atallah, Ahmad, (2011), "Creative Supervisory Practices of the Educational Supervisors, As Viewed by the UNRWA Schools Teachers, Gaza", Unpublished MA Thesis, Faculty of Education, Gaza, Palestine...

8. Fitzgibbons, D. (2005). Transformig Business and Education: The Challenge to Organizations and Educator. Organization Development Journal, 21 (4) 6-15.

9. Gordon, s. (2000). Supervision of Instruction, A developmental Approach, 4th ED, Allyne and Bacon: Boston.

10. Idrees, Mohammad, "Evaluation of the Supervisory Practices in the Schools of Irbid Governorate"; Unpublished MA Thesis, Al-Yarmouk University, Irbid.

11. Masa'adeh, Wasfi, (2001), "Impediments of the Educational Supervision, as Seen by the Supervisors of the Directorates of Education in the Northern Governorates", Unpublished MA Thesis, Al-Yarkouk University,

12. Ministry of Education, (2012), "Educational Supervision Guide", Amman.

13. Narango. F. V. (1993) Educational Supervision in Colombia: the role of the supervision: Dissertation Abstract International, 68 (4) 321. 
14. Safar, Salheh, (2008), "Distant Educational Supervision between Importance and Practice, and Its Usage Impediments", Unpublished Doctoral Dissertation, Faculty of Education, Umm Al-Qura University, Saudi Arabia.

15. Sullivan, Susan \& Jeffery, Glanz (2000). Alternative approaches to supervision: cases from the field. Journal of Curriculum \& Supervision, Spring 15(3) 77-95.

16. Ting, Yi-kup, Chang Derray (2006). The Impact of Clinical supervision on the Teaching Effectiveness of primary school student teachers. Journal of National Taiwan Normal University, 2 (51) 219-239. 